\title{
Peripheralisation: The Missing Link in Dealing with Demographic Change?
}

\author{
Tim Leibert, Sophie Golinski
}

\begin{abstract}
Demographic change is an uneven spatial process in Germany. Depopulation and ageing have become pressing issues in most rural regions. In connection with low population densities and the financial difficulties of municipalities and service providers in rural regions, these demographic trends have led to a discussion about the future provision of services of general interest and - more broadly - the postulate of equal living conditions which was for a long time the basic principle of spatial development in Germany. In this paper, we argue that the peripheralisation approach is a helpful tool to better understand how interaction of out-migration, dependence, disconnection and stigmatisation shape the future of rural regions. We also discuss the impact of peripheralisation on the development and implementation of adaptation strategies. Based on the 3R-model (retrenchment, repositioning, reorganisation), we argue that adaptation strategies can reinforce (retrenchment) peripheralisation processes, but also serve as groundwork for the formulation of policies aiming at de-peripheralisation.
\end{abstract}

Keywords: Peripheralisation - Demographic change $\cdot$ Adaptation strategies $\cdot$ Public services · East Germany

\section{Introduction: The demographisation of the debate on the future of rural areas}

Territorial inequalities are increasing in all parts of the developed world. The reasons underpinning the growing rift between prospering cores and declining peripheries are essentially the same. America's "rural ghettoes", the "désert français" and decaying villages of East Germany are all similarly affected by remoteness, structural economic weaknesses, long-term unemployment, out-migration and ageing (Neu 2006). The depopulation of already sparsely populated regions combined with the budgetary crisis affecting public authorities has resulted in a controversial debate 
about the future provision of services of general interest as well as of social and technical infrastructures in the countryside. A striking feature of this debate is the lack of consideration for rural populations - aside from calls for more civic participation. Demography, on the other hand, is omnipresent, be it in terms of infrastructure costs per capita, minimum populations, carrying capacities and the size of catchment areas. The demographisation of the debate on the future of rural areas can be summed up in one sentence: demography becomes destiny. It is assumed that the structure of the population determines the future prospects of any given society or region (Neu 2009: 83). Social, economic and cultural drivers are factored out or interpreted as a mere consequence of demographic changes (Beetz 2013: 55).

The demographisation of social phenomena is a highly persuasive mechanism. Demographic trends are increasingly treated as inherent necessities and used to legitimise reform proposals (Berger/Kahlert 2006: 10). They are also utilised as arguments against political agendas that have become integral parts of the self-conception of the Federal Republic of Germany, such as the paradigm of balanced spatial development and the idea of equitable living conditions in all parts of the country (Neu 2009: 84; Canzler/Knie 2009: 97). These formerly unquestioned political goals are increasingly being perceived as obstacles in the process of making rural regions "fit for the future" (see e.g., Klingholz 2015; Canzler/Knie 2009: 106-107). There seems to be an emerging societal consensus on the fact that the constitutional mandate guaranteeing equitable living conditions in sparsely populated rural regions is no longer applicable (Barlösius/Neu 2007: 79). Instead of "thinking outside the box" and developing innovative solutions that go beyond short-term pilot projects, the future of infrastructures and public services in rural regions is discussed in terms of minimum standards, subsidy requirements, and cost recovery. Reinterpreting the future of rural regions as an inevitable "demographic destiny" implies excluding this question from the political decision-making process, nipping in the bud discussions regarding the organisation of territorial and social cohesion in Germany (Barlösius/ Neu 2007: 88). This reinterpretation also eludes how approval procedures, administrative processes, allocation of tasks between the state, the market and the citizens as well as competences and funding of local governments could be adapted in order to allow for the implementation of more innovative solutions.

This paper has two main aims. The first one is to add an additional perspective to current research on the causes and consequences of demographic change as well as on possible adaptation strategies. Following Lang (2012: 1749), we argue that the causes and consequences of shrinkage and ageing can be better understood by using the concept of peripheralisation: namely since uneven spatial developments are linked to societal processes as well as to supraregional and even supranational developments. Our second aim is to bring rural people (back) into the focus of research on rural restructuring. It has been argued that the response of people living in sparsely inhabited and depopulating rural regions to service cuts and the dismantling of services of general interest and of technical and social infrastructures is hardly taken into account (Hyll/Schneider 2011: 217-218). This is due to the fact that the adaptation of services and infrastructures to a decreasing population is in the 
first place perceived as a technical problem of quantities, not as a social problem of participation and exclusion.

This paper is structured as follows. The second section centres on regional peripheralisation and addresses the four sub-dimensions of this concept, namely outmigration (section 2.1), disconnection (section 2.2), dependence (section 2.3), and stigmatisation (section 2.4). In a short case study (section 2.5), we consider the Land of Saxony-Anhalt to empirically illustrate peripheralisation processes and their spatial effects under conditions of demographic change. Section three deals with the influence of peripheralisation on the adaptation of public services. We discusses the 3R-model (retrenchment, reorganisation, repositioning) as an analytic concept of possible adaptation strategies in the triangle of conflicting priorities between tight budgets, demographic change and the principle of equivalent living conditions enshrined in the German Constitution. In section 4, we sum up the most important findings and shed light on future research issues.

\section{Theorising peripheralisation: The interplay of out-migration, disconnection, dependence and stigmatisation}

Peripheralisation is the process of producing and reproducing peripheries through mechanisms of out-migration, disconnection, dependence, and stigmatisation (Kühn/Weck 2013: 24), which lead to the "gradual weakening and/or uncoupling of the socio-spatial development in a given region vis-à-vis the dominant process of centralisation"1 (Keim 2006: 3). Peripheralisation is driven by the action of certain actors, which, in turn, means that peripheries are not only determined by geographical location or the quality of the transport infrastructure (Kühn/Weck 2013: 24), but also by purposive decisions and their - often unintended - side effects. There are, hence, no distinct indicators or thresholds that can be used to transform peripheralisation into a statistically tangible and mappable concept (Lang 2012: 1751). Both Kühn/Bernt (2013: 312) and Lang (2012: 1751) stress the relational nature of peripheralisation. The former argue that peripheralisation is a process consisting in downgrading a specific region vis-à-vis other regions, while the latter underscores the role of normative interpretations by pointing out that centre and periphery emerge in overall societal discourses.

Peripheralisation is, consequently, not an independent process, but a logical consequence of centralisation. As the two sides of the same coin, both processes "form a complementary as well as contradictory dialectic unit" (Kühn/Bernt 2013: 303). Centralisation and peripheralisation are characterised by antithetic socio-spatial processes: autonomy/dependency; inclusion/exclusion; hegemony/stigmatisation; growth/decline; in-migration/out-migration (Kühn 2015: 375). Centralisation hence leads to the concentration of people, economic power, and infrastructure in metropolitan areas at the expense of other, mostly rural, regions. The main consequence of peripheralisation is a process of cultural, demographic, economic, and social con-

1 Direct quotes from German texts have been translated by the authors. 
traction, which leads to an increasing specialisation of a once multifunctional region to a restricted number of uses and activities (Keim 2006). Taken together, peripheralisation results in a permanent consolidation of structural deficits and restrains opportunities for the resident population (Beetz 2008). These structural deficits are not necessarily economic in nature, as peripheralisation is a multi-dimensional and multifaceted process that also includes demographic, social, infrastructural, cultural, and political aspects (Kühn 2015). Fischer-Tahir/Naumann (2013: 18) add a different angle to this reasoning by linking peripheralisation and marginalisation in order to point out that "peripheralisation refers to a spatially organised inequality of power relations and access to material and symbolic goods that constructs and perpetuates the precedence of the centres over areas that are marginalised".

Yet, there is not even a consensus whether peripheralisation is still a predominantly spatial process. Copus (2001: 539) argues that - due to changes in the economic environment "in future peripherality will increasingly become an aspatial issue". The relevant economic and technical developments are improvements in the transport and communication infrastructure, structural changes in the industry structure, in particular the expansion of the service sector at the expense of agriculture and heavy industries, and the advent and dynamic development of the information society, including the increasing importance of e-commerce (Copus 2001: 544). These changes have - at least in theory - lead to a decreasing importance of distance, travel time and transportation costs. "Aspatial peripherality" is hence not characterised by geographical location, but by the lack of embeddedness in business and institutional networks, poor access to and/or availability of social capital and information and communication infrastructures as well as weak links to global markets and information networks (Copus 2001: 544-546). Other authors, e.g. Balogh (2015), Lang (2015) or Paasi (1995) view peripheries and peripherality as socially constructed. Peripheralisation as the act of (re)producing peripheries is hence the result of socio-material and discursive processes (Balogh 2015).

The conceptualisation of peripheralisation goes beyond the "taken for granted" (Paasi 1995: 235) understanding of the meaning of periphery and peripherality: "Peripherality generally connotes distance, difference and dependency. A typical periphery is geographically remote, economically lagging, dependent upon external political and industrial decision-making, and culturally obsolete" (Eskelinen/Snickars 1995: 1). Based on this definition, "peripheralisation" would be a process which results in a given region becoming more remote or less accessible, economically less viable and politically more dependent. One could even distinguish "active" and "passive" peripheralisation - the former caused by purposefully cutting transport links, closing businesses and limiting the political influence of (the inhabitants of) a specific region. "Passive peripheralisation" would on the other hand imply that the region in question falls behind because it cannot keep up with the development of the centre. The most important additions of peripheralisation as a theoretical concept can be summarised as follows: (1) Peripheralisation is relational: Peripheralisation implies processes of centralisation and vice versa (Lang 2015: 175). (2) Peripheralisation is a social process, not a geographical fact. Discourses and images 
play an important role in this context (Balogh 2015; Bürk 2013). (3) Peripheralisation is dynamic and reversible.

In the following four sections, we critically discuss the four dimensions of peripheralisation identified by Bernt/Liebmann (2013): out-migration (demographic peripheralisation), dependence (being in a marginal position in superordinate networks), disconnection (infrastructural peripheralisation and being on the margins of information society) and stigmatisation (discursive peripheralisation). This list was developed in a research project analysing how middle-sized towns in Germany deal with processes of peripheralisation. Against this backdrop, the four characteristics and their weighting need to be reconsidered and expanded according to different research questions. We believe, for instance, that there are two additional aspects of peripheralisation - social peripheralisation (i.e. social exclusion) and political peripheralisation (i.e. a distancing of larger parts of the population from democracy, expressed for instance in low voter turnout and a high percentage of votes for extremist parties) which are strongly interwoven with, yet only implicitly covered by these four dimensions. Making social and political peripheralisation more explicit would also answer Lang's (2015: 180) call to pay more attention to how "ordinary people" deal with the processes of peripheralisation. This call indicates that the local civil society currently takes an (undeserved) backseat in research on peripheralisation.

Peripheralisation is a multilevel phenomenon that can affect whole regions, specific settlements, but also individuals. The former is especially true for the four "classical" aspects of peripheralisation, the latter for social and political peripheralisation processes as well as the strategies "ordinary" people develop to deal with the challenges of peripheralisation for their lives. There are, on the other hand, segments of peripheralised regions or societies that are less affected by peripheralisation, e.g. the municipalities where the services of general interest are centralised. This potential of peripheralisation as an overarching concept for multi-level research, especially the potential to link processes and developments at the macro level to their consequences at the micro level, should be strengthened in future empirical work and theoretical discussions. The fact that peripheralisation is a relational process, meaning that it is always connected to a process of centralisation, and a multidimensional process is in our opinion a major advantage vis-à-vis other concepts: Since peripheralisation focuses on the interplay of multiple actors on various levels and can therefore lead to a better understanding of how people, communities or regions are pushed to the margins and their leeway to deal with or even resist becoming a periphery. The idea that peripheralisation is both reversible and a "constitutive element of capitalism" (Fischer-Tahir/Naumann 2013: 10) allows for a more comprehensive perspective of the possible impact of adaptation strategies and best practices for regional development. The link of peripheralisation and adaptation is further elaborated in section 3. 


\subsection{Out-migration}

Out-migration is, according to Bernt/Liebmann (2013: 219-220), the primary indicator of peripheralisation. Leaving can be interpreted as a voting "with one's feet". Out-migration is usually a selective process, i.e., some subgroups of the population are more likely to leave than others, e.g., young women (Leibert 2016; Wiest) Leibert 2013; Kühntopf/Stedtfeld 2012). Many rural adolescents have long before school assimilated that "all of the pathways to success that are understood to be strategic and/or successful are premised on pathways that lead [them] out of their rural homes and communities" (Looker/Naylor 2009: 54). This brain-drain of the young, highly qualified, and well-educated people is an important barrier to "deperipheralisation" because it weakens the innovative potential of peripheries while inhibiting the development and implementation of new ideas and strategies (Bernt) Liebmann 2013: 220; Kühn/Weck 2013: 31).

Migration should, however, not be solely interpreted as a threat for rural regions. Out-migration is also a "pre-requisite for rural economic regeneration" (Stockdale 2006) since the availability of appropriate "human capital" is a crucial aspect of endogenous regional development. Migration is usually a precondition to the acquisition of the skills and knowledge necessary to participate in the economic regeneration of rural regions, as institutions of higher education are mostly urbanbased. The problem lies therefore not in out-migration per se, but in the weakness of the reverse flow, meaning that too many out-migrants go for good. Migration is hence a double-edged sword for rural regions: Unlike the popular stereotype which contrasts the "stable countryside" with the "hypermobile city" (Milbourne/Kitchen 2014), rural regions are intensely affected by mobility such as out-migration of the youth, in-migration of retirement migrants, "passing through" of tourists or longdistance labour mobility of weekend commuters. They all do affect rural areas in similar ways. This ambiguity of mobility can be translated into a rural mobility paradox: "on the one hand, [rural places] require mobilities to remain sustainable [...] while, on the other these same mobilities have the power to destroy the essence of the place" (Milbourne/Kitchen 2014: 335). Even sedentariness is not equivalent to stability and immobility. Mobility (e.g., in terms of commuting) is increasingly used as a means to gain stability and to be able to remain in rural regions with a degraded job market or in regions in which mobility and long distance travel for the purpose of basic needs satisfaction is compelled by the withdrawal of state and market institutions (Walsh 2012: 137). An open question is how to deal with the consumption of rurality, notably counter-urbanisation, second homes and travel (both tourism and day trips) (see e.g. Halfacree 2012) i.e. temporary in-migration of people who value that "time stands still" and that the region in question is disconnected from modern life. Since the consumption of the countryside involves a repositioning of services and infrastructures to the needs of the inhabitants of the centres, this form of in-migration can also be considered as a manifestation of peripheralisation (i.e. another form of dependence), but one that helps to maintain a certain level of services of general interest in depopulating regions. 


\subsection{Disconnection}

Disconnection can be understood as a progressive disconnection of the peripheries from regulatory systems like the state or the market based on decisions made in the centres of economic and political power (Kühn/Weck 2013: 33). This process is in the first place related to not having or losing access to economic powerhouses and has two dimensions: disconnection from infrastructure and disconnection from economic and social innovation (Neu 2006). In economic terms, peripheries can be defined as areas characterised by a lack of local and/or regional innovative capacities, which translates e.g., into the absence of institutions of higher education, low qualification of the workforce or low intensity of research and development activities of local enterprises (Kühn/Weck 2013: 33-34). Disconnection originates in the first place from a non-dynamic knowledge economy sector and a disintegration of the link to advanced value-added processes (Bernt/Liebmann 2013: 220).

In infrastructural terms, disconnection is related to a constrained access to the economic centres of gravity, thereby reinforcing and perpetuating spatial inequalities (Naumann/Reichert-Schick 2015: 1). The existence of technical and social infrastructures and the provision of services of general interest are crucial for regional development (Reichert-Schick 2013: 34); this applies particularly to transport infrastructures. Demand for mobility increases given that adaptation strategies most frequently consist in a centralisation of services of general interest in middle-sized towns ("people to services"). The need for a well-developed road network is hardly questioned since dependence on private car transportation is a key feature of peripheral regions (Osti 2010: 306). The future of public transport in sparsely populated rural regions, on the other hand, is a topic that can easily fill volumes (see e.g., Canzler/Karl 2010; Holz-Rau et al. 2010; Steinrück/Küpper 2010). The abandonment of publicly funded transport in sparsely populated rural regions is not a taboo in this context (e.g., Canz/er/Kar/ 2010). Apart from fiscal arguments, proponents of phasing out or radically remodelling the provision of services of general interest in rural peripheries argue that it is morally questionable whether the public (i.e., the tax-payers in the core regions) should subsidise the residential preferences of rural residents. According to this view, the implementation of a "user-pays" principle is proposed to cut infrastructure costs in the countryside (Holz-Rau et al. 2010: 493, 502).

The disconnection from economic and social progress and from technical and social infrastructures lead to social exclusion of the more vulnerable segments of rural societies - which might indeed be added as an additional fifth characteristic of peripheralisation, notably children, the elderly, the poor, the unemployed, people with no cars and those without effective support networks. Social exclusion has three core dimensions: (1) exclusion from economic life, (2) exclusion from social services, and (3) exclusion from civic life and social networks (Spoor 2013: 140-141). The most important driver of social exclusion is a constrained access to mobility on an individual level, which is the most important precondition for participation in social and professional life (Hauss et al. 2006: 35). Disconnection hence results in mobility restrictions for parts of the rural population. It seems that social exclusion is rather widespread in rural East Germany (Laschewski 2009: 105). This is, for in- 
stance, transcribed in very high levels of long-term and youth unemployment, child poverty and strong dependency on transfer payments.

\subsection{Dependence}

Unequal power relations between centres and peripheries are another key aspect of peripheralisation. The peripheries are dependent on decisions which are made in the centres and on which they have hardly any influence, e.g., with respect to location decisions, investments or allocations of funds (Beetz et al. 2008: 305; Kühn/ Weck 2013: 41): "The relation of centre and periphery is less a spatial fact than a social configuration resting on unequal power relations which lead to uneven spatial development. The political dimension is characterised by power in the centre and powerlessness at the periphery" (Kühn 2015: 375). The political and economic decision and control functions in Germany are mostly concentrated in the largest cities, notably Munich, Berlin, and Düsseldorf (Kühn/Weck 2013: 37). Smaller cities, including some state capitals, are largely deprived of decision-making centres, especially due to the absence of major enterprise's headquarters (Kühn/Weck 2013: 37). The economic polarisation fades somewhat if global market leaders - many of which are small and medium-sized businesses - are taken into account. About one fifth of such "hidden champions" are located in municipalities that can be characterised as "peripheral" or "very peripheral", especially in Baden-Württemberg and Bavaria. World market leaders are, on the other hand, notably absent in rural East Germany (Ermann et al. 2012).

Dependence is also connected to the funding of local governments. Many rural municipalities only have limited freedom of action as a result of low fiscal revenues, high welfare expenses and debt servicing as well as financial constraints caused by misguided investments in the past (Beetz et al. 2008: 300). The result is a permanent dependence on transfer and equalisation payments as well as on budget appropriations (Kühn/Weck 2013: 37), leading to a keen competition for state, federal and European funds. This translates into an alignment on grant requirements and the programme's objectives. Hence, local governments are often unable to pursue consistent long-term development strategies based on specific local challenges and locally available resources. The changing philosophies, objectives, and rules of the subsidy programmes as well as the limited duration of funding periods and pilot projects do dictate a constant reorientation of local approaches. Regional development policies turn into a "strategic management of dependencies" (Bernt/Liebmann 2013: 226).

It would, however, be short-sighted to assume that peripheralised regions (and their inhabitants) are per se "victims of [...] overarching processes beyond their control" (Lang 2015: 176). While Kühn/Weck (2013) are certainly right with respect to the limited (financial) leeway of many rural municipalities, the agency of other stakeholders is often neglected in discussions about rural futures. Lang (2015: 180) argues that forms of agency can cover a spectrum ranging from reproducing the existing core-periphery relations to resistance. One notable (and finally successful) example of local resistance to decisions made in the centres is the "rebellion in the 
classroom" (Steffen 2013) which took place in the small town of Seifhennersdorf (Saxony). In answer to the decision to close the local secondary school, the parents took matters in their own hand - by breaking the law: The pupils refused to attend the school they were assigned to and instead attended classes in Seifhennersdorf, where retired teachers gave the lessons. The municipality has backed this civic disobedience and contested the school closure in court. In the end, the Federal Constitutional Court declared the Education Act of the Free State of Saxony on which the decision to close the school was based to be unconstitutional (Seibe/ 2014). Other examples for agency in the periphery are "Raumpioniere" (literally "spatial pioneers") who develop on their own initiative innovative and tailor-made solutions in order to find new ways to sustain services of general interest (Faber 2013) and social entrepreneurship which aims at solving the problems of declining rural peripheries with marketable products and services (Federwisch 2014: 100). One should, however, not overlook that peripheralisation is often connected to social exclusion (Leibert 2013: 105-109). Social exclusion, especially unemployment, is linked to a loss of regional human capital (Ebenrett et al. 2003). Since human capital seems to be an important precondition to become a "Raumpionier" or a social entrepreneur, the question remains open whether the history of peripheralisation, especially the degree of selective out-migration in the past, limits regional agency capacities. We will get back to this question in section 3.3.

\subsection{Stigmatisation}

Stigmatisation is the fourth dimension of peripheralisation. In contrast to Bernt/ Liebmann (2013: 219-220) who regard out-migration as the core indicator of peripheralisation, we believe that stigmatisation is the root cause of the consolidation of peripheralisation. The perception of a given region by its inhabitants and by external stakeholders (e.g., national politicians, potential investors) does influence location decisions of all sorts: Whether to leave or to stay, whether to (dis-)invest, whether to establish, maintain or abandon services of general interest. In discourses on rural peripheries it is sometimes claimed that the negative consequences of peripheralisation are results of a failure of local governments and civil societies. ${ }^{2}$ One example is the notion of "lost regions", where "no innovators can be found that try to create a future" (Weber/Klingholz 2009: 3). Structural problems, on the other hand, are less frequently acknowledged; the responsibility for "arrested development" is allotted to the peripheries themselves (Bernt/Liebmann 2013: 221): The ascription of the failure to enter a virtuous circle of successful regional development to regional politicians and ultimately to the regional population itself fosters a negative regional image. The unfavourable development trends become a characteristic of the whole place (Bernt/Liebmann 2013: 221). This is especially apparent in the media cover-

2 See e.g. Bürk's (2013) analysis of the stigmatisation process of Sangerhausen (Saxony-Anhalt) and the "discursive violence inflicted on the city" (2013: 175). Bürk (2013: 180) interprets the (politically motivated and ideologically informed) stigmatisation of single places and regions as being about "'blaming the victim' of new state spaces". 
age of rural peripheries and other demographically and/or economically declining regions. In recent years, the national press has, for instance, repeatedly picked up on the depopulation and ageing process undergone by the East German countryside linking demographic change with dramatising descriptions of moribund towns and villages hallmarked by poverty, hopelessness, and out-migration of the "best and brightest". Headlines like "Empty East: only the footsore stay", "Ocean of poverty and dementia" or "drinking contests in the depression zone" (Speck/Schubarth 2009: 15) contribute to paint a gloomy picture of rural East Germany. Stayers who are depicted as a "negative selection" of society are given particularly bad press. This is especially true for young men who are often portrayed as unemployed and uneducated boozers with right-wing world views (Rolfes/Mohring 2009: 77-78).

The demographisation of the discourse on rural infrastructures in the political and scientific spheres can be perceived as a form of stigmatisation and marginalisation that has especially far-reaching consequences. Regional policy is, as Lang (2015: 176) points out, "always normative [...] and framed by individual and collective values linked to specific understandings and conceptualisations of development, desired policy outcomes and funding priorities". Removing the rural population from the picture can lead to policy recommendations such as the - fiercely criticised (Steffens/Kröhnert 2009: 219) - proposal of an "orderly retreat" (Klingholz 2015: 27) from the "lost regions" mentioned in the previous paragraph. Given the high costs of providing and maintaining social and technical infrastructures in rural areas, it is proposed that residents of "fading places" - small villages with an overaged population in sparsely populated regions - should receive a bonus payment to encourage them to move to urban agglomerations or regional centres (Berlin-Institut 2007: 30; Steffens/Kröhnert 2009: 218): "The government of the Land should communicate in ["lost regions"] that an ongoing emptying-out is inevitable in the long run. Trying to prevent it would possibly be considerably more expensive than to allow it or even support it" (Steffens/Kröhnert 2009: 219). The stigmatisation and marginalisation is somewhat implicit: Rural regions are portrayed as places that have absolutely nothing worth preserving for future generations. This label is probably even more detrimental for the future of rural areas since the public tends to readily accept the reasoning that a specific service of general interest has legitimate reasons to be cut when labelled "too expensive". Convincing voters that rural regions are a considerable burden for the budget and that the tax payers' money would be better spent elsewhere (i.e., in the centres) is an especially powerful tool, helping to legitimise policies that result in infrastructure cutbacks.

There is a risk that the inhabitants of demographically and economically declining rural regions themselves incorporate this perception. Feelings of being left behind and forgotten, of living in a place that has had its days can affect regional identities and lead to senses of hopelessness, a "mental peripheralisation" (Kühn/Weck 2013: 39) that blocks innovation and creates isolated milieus as well as increases apathy of the population (Reichert-Schick 2013: 37). Negative internal and external images can hence lead to mental lock-ins and paralyse whole regions, resulting in a downward spiral that is hard, but not impossible to break (Lang 2012: 1751). 
In the next section, we present a short case study in order to shed more light on the interplay of the processes of peripheralisation discussed in sections 2.1 to 2.4, in particular the links between stigmatisation and out-migration.

\subsection{A case study of peripheralisation: Saxony-Anhalt}

Saxony-Anhalt is the German Land with the most unfavourable population development. As such, it is chosen to exemplify peripheralisation "in action". The demographic situation is characterised by a severe ageing dynamic and pronounced depopulation; in particular, in the remote and sparsely populated rural regions (Leibert/Köpp/ 2015). In this context, strong age- and sex-selective out-migration has emerged to be the most important driver of both depopulation and ageing. Young women in their early 20s have been more likely to leave the rural areas than coeval men (Wiest/Leibert 2013: 459-460), leading to a pronounced "deficit" of young women in many rural municipalities (Kühntopf/Stedtfeld 2012: 29-36; Leibert 2016: 268). These trends contribute to a distorted age- and sex-structure of the population, eventually resulting in a lack of potential mothers and simultaneously weakening the overall reproductive potential (Leibert 2016). Figure 1 shows that outmigration of young adults - the first basic dimension of peripheralisation (section 2.1) - is a comprehensive phenomenon in rural Saxony-Anhalt. Net migration gains are largely restricted to the regional centres, selected district seats (Kreisstädte) and medium-sized towns hosting institutions of higher education. The few rural municipalities exhibiting positive migration balances are in most cases those places with accommodation centres for asylum seekers (Leibert/Köpp/ 2015: 63).

In addition to demographic problems, Saxony-Anhalt is also burdened with socio-economic problems such as unemployment and child poverty (Table 1) as well as structural economic weaknesses (e.g., a weak innovation potential of the regional economy or a low wage level), both resulting in low levels of tax revenues (Table 1). Low fiscal revenues, in turn, generate structures of dependence, namely unequal power relations and dependence on funds and investments coming from outside the region.

It is likely that the stigmatisation of East Germany (section 2.4) and its inhabitants in the media, its bleak socio-economic outlook, perceptions of lacking career prospects, and selective out-migration of young adults are factors that do exacerbate each other. Media reports usually interpret out-migration of young people, especially of young women, as a barometer of future prospects of a respective region. Besides, public opinion is heavily influenced by reports on right-wing extremism, alcoholism, poverty, devastation, and desperation, which again enforces the migration patterns of young people. The ones who stay within the region are branded as "the stupid remainders" (Speck/Schubarth 2009: 15). Youth are sensitive to media coverage when it comes to making major life decisions, and they, as a consequence, have little faith in the future sustainability of East Germany (Beetz 2009). These findings are supported by results of a survey conducted among pupils and by in-depth 
Fig. 1: Migration balance of young adults in Saxony-Anhalt by municipalities 2012/13

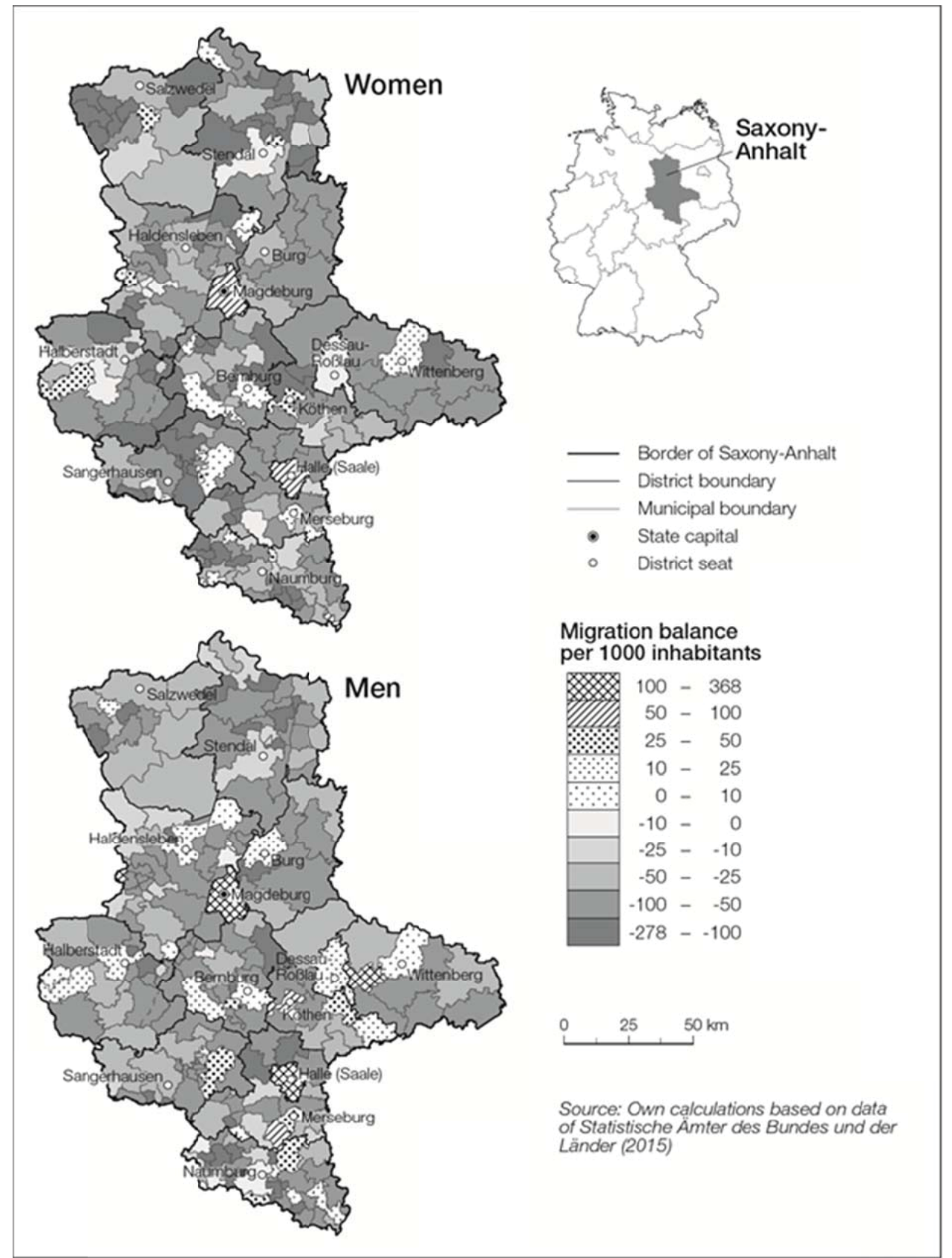

Source: Own calculations based on data of the Federal as wells as Regional Statistical Offices (Statistische Ämter des Bundes und der Länder 2015) 
Tab. 1: Selected indicators of peripheralisation: social exclusion

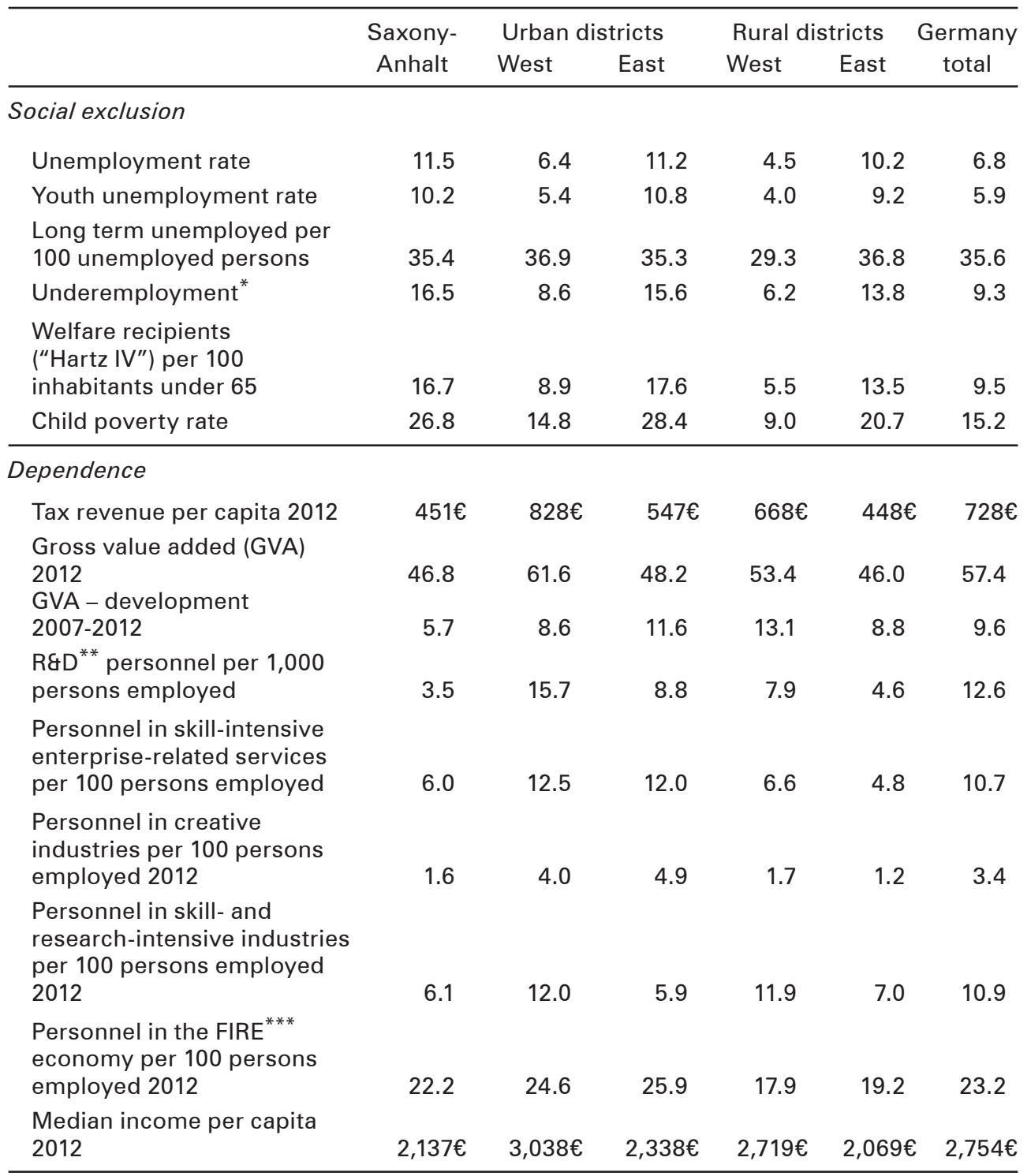

* Proportion of the workforce employed on the subsidised labour market (e.g. job creation schemes, vocational re-training)

** Research and development

*** Finance, Insurance and Real Estate

Source: BBSR 2015 
interviews with young women carried out in the context of the ESPON SEMIGRA ${ }^{3}$ project (see Leibert/Wiest 2012 for details). A large majority of the surveyed pupils are deeply convinced that their home region has no future, and that moving away is a necessary precondition for a successful professional career. The survey results further indicate that young people view regional living and labour market conditions in rural Saxony-Anhalt as hopeless and very unappealing. An overwhelming majority considers it difficult or nearly impossible to find a job, earn a living, and be successful in their rural home regions. The young people are not necessarily counting the days until they can finally leave, but they are not reluctant to move away either: Only a third of the interviewees agreed that it would be painful for them to move away from their native region (Wiest/Leibert 2013: 462). The reasoning behind this grudgingly accepted mobility is that remaining in the countryside and becoming successful are perceived as mutually exclusive options, as the following statement reveals: "I would very, very much like to leave the rural area in order to improve my occupational outlook and to promote my career" (male pupil, Harz district). Such aspirations are fostered by perceptions of hopelessness afflicting home regions, but also by the "lure of the center", which is regarded as a place to settle down permanently, a place where a variety of well-paid jobs are available: "I think I'Il live [...] in Bavaria [in 10 years]. I've always been attracted by this region and rumor has it that there are better career opportunities. I'll start a family there and build a house" (male pupil, Altmarkkreis Salzwedel). Young people tend to contrast opportunities available in rural regions with those offered in urban areas. The perception of a socio-economic disconnection of rural Saxony-Anhalt from economic centres, which translates into a feeling of spatial and social marginalisation, is a central topic within interviewees' narratives (Wiest 2016: 285). This indicates that home region peripheralisation is not an abstract concept for young people growing up in the East German countryside, but a reality they happen to experience every day. The parents of the interviewed pupils share the perception that rural Saxony-Anhalt is a declining periphery that has nothing to offer for ambitious young people. Against this backdrop, many parents advise their offspring to leave, often years before they even graduate: "My daughter is eleven, an age at which you don't really have to start planning for the future, but as her mother, I tell her she won't stay here. She has to move away at some point, because she won't be happy here. [...] She's eleven, so she really shouldn't have to be thinking about these things yet, but as her mother, I tell her she won't stay here." (unemployed woman, Stendal district). The peripheralisation of rural Saxony-Anhalt has hence resulted in a "culture of migration" (Wiest) Leibert 2013: 463-464; Leibert 2015: 38-39): Staying is equated with failure, while leaving is perceived as being a very promising road towards success.

3 The ESPON 2013 SEMIGRA (Selective Migration and Unbalanced Sex Ratio in Rural Regions) project (2010-2012) aimed at identifying the main reasons and consequences of age- and sexselective migration in rural regions of Finland, Germany, Hungary and Sweden. 


\section{The 3R-model: Adaptation (strategies) in theory and practice}

Peripheralisation can be understood as a "missing link" insofar as this concept stresses the interconnectedness of political, economic, demographic and ideational factors, which tend to be overlooked when questions of regional development are "demographised". One of the most important lessons is that concepts of adaptation to demographic change in rural regions have to consider all four dimensions of peripheralisation: out-migration, disconnection, dependence and stigmatisation. On the one hand, we hypothesise that neither infrastructural cutbacks nor placebased strategies do fully acknowledge all the dimensions of peripheralisation yet. On the other hand, processes of out-migration, dependence, disconnection, and stigmatisation can severely limit a region's ability to develop and implement adaptation strategies in order to improve regional living conditions and enhance economic potentials. More precisely, peripheralisation processes do constrain the region's operational leeway in matters of adaptation to demographic change. They do affect the region's autonomy to act (e.g., in terms of competences and funds), their ability to act (e.g., in terms of developing innovative measure) and the amount of resources available to them to act (e.g., in terms of infrastructure, social and human capital). One should always keep in mind that different regions have their own contextual particularities, both in terms of problems to be tackled and resources available. In other words, instruments and measures that are successfully implemented in one region may not work at all in another. An additional link between peripheralisation and adaptation is the normative nature of regional policy (Lang 2015: 176) which is relevant for the design of adaptation strategies. Meaning the question in which regions strategies of Retrenchment and centralisation are pursued and in which regions a Repositioning and Reorganisation of the services of general interest is implemented. Before we discuss this $3 R$-modell in the public sector using examples from the field of rural public transport (section 3.2) we first briefly turn to the current discussion on the paradigm of equal/equitable living condition in Germany (section 3.1) and conclude with some reflections on whether voluntarism is an ubiquitous locational factor - to borrow a term form industrial location theory (section 3.3).

\subsection{Adaptation to what? - Objectives of action}

The constitutional obligation towards the creation of equitable living conditions in all parts of Germany is enshrined in article 72 (2) of the Basic Law of the Federal Republic of Germany. More specifically, the German federal planning law (Raumordnungsgesetz) refers to living conditions as an aggregation of several dimensions including economic performance, the labour market, health care, material prosperity, the housing market, the education system, culture, the technical infrastructure, mobility, and the environmental situation (BBSR 2011: 16). It does not mean that the same living conditions should be found everywhere ("equal"), but rather that a standard level of services of general interest should be met ("equitable"). In order to limit spatial disparities, the welfare state aims at providing a minimum level of services of general interests in all parts of Germany (Einig/Jonas 2009: 130). The 
paradigm of equitable living conditions is limited to services of general interest, i.e. public services provided and/or supported by the federal, regional or local governments or their agencies (öffentliche Daseinsvorsorge), whereas private services are largely beyond the scope of governmental authority. Public services include both technical infrastructures (e.g., water supply, sewage disposal, energy supply, waste collection and treatment, public transport) and social infrastructures (e.g., education, health care, culture, sports) (Kersten et al. 2015: 9).

In 2006, new guiding principles regarding the spatial development of Germany (Leitbilder der Raumordnung) were enacted in order to achieve equitable living conditions while accepting a basic level of divergence among regions. One of the principles has been explicitly dedicated to secure the provision of essential public services and addresses the threat posed by demographic change and its consequences (BBSR 2015). The continued adherence of law-makers to equitable living standards in Germany has cyclically provoked ideological disputes. Whereas supporters justify equitable living standards by recalling the basic functions of a welfare state, opponents condemn the paradigm in order to rule out compensational actions remedying the locational disadvantages of lagging regions (e.g., Canzler) Knie 2009; Elbe/Müller 2015: 57; Klingholz 2015: 25). In general, the obligation of equitable living conditions in all parts of Germany remains one of most important objectives of the German spatial policy which provides orientation and determines adaptation strategies. In terms of the provision of public services and facilities in rural areas, current adaptation strategies seem to be providing a set of useful tools, but recent research also recognises that long-term, sustainable and comprehensive structures are still implemented insufficiently (e.g., Steinführer et al. 2014; Beetz et al. 2008).

\subsection{Adaptation and peripheralisation: The 3R-model}

Although numerous political discussions, maintenance efforts, and funding programmes have been conducted in response to demographic changes, current research has focused little on the adaptation of public sector organisations (Boyne 2004: 97). Several studies, related to organisation studies, have assigned concepts on organisational decline and turnaround of private organisations to the public sector. In other words, strategies of adaptation, which are pursued by private organisations in order to increase their performances, are assumed transferrable to nonprofit organisations. Primarily focused on the private sector, a substantial body of work on organisational turnarounds has investigated numerous activities operated by failing organisations. As a result, it has been found that organisational recovery can be managed through three different adaptation strategies (3R-model) - retrenchment, reorganisation, and repositioning - (Walshe et al. 2004: 201; Boyne 2004: 98). Retrenchment basically indicates the reduction in scope or size of an organisation, thus immediately scaling down finances and costs. Kersten et al. (2015: 12) give a brief and simple description of what retrenchment means: "Less population + less money = less infrastructure". Reorganisation or replacement, instead, aims at changing the internal structure of an organisation. By replacing members 
of the management, or beyond, internal changes are favoured over alterations in an organisation's size or market position. Finally, repositioning or renewal results in changing the entrepreneurial strategy of an organisation. Longer-term actions involve fundamental shifts in vision, activities, and markets in response to changing external circumstances (Küpper 2011a: 89; Walshe et al. 2004: 204). Boyne transferred the existing theory on failure and turnaround from the private to the public sector. He acknowledged that public services of general interest are also confronted to fast-changing demands and, therefore, have to accordingly adapt their supply structures. Drawing lessons from the profit-seeking sector, retrenchment suggest that non-profit organisations withdraw from the market completely. This is, however, problematic as local authorities are usually obliged to provide certain services. Hence, retrenchment strategies are solely applicable if exit strategies are only partial or the responsibilities are shifted to other, external organisations (Boyne 2004: 100). Strategies of reorganisation in the public sector encompass broad changes in the organisation culture, such as the decentralisation of responsibilities or the internal implementation of new concepts of service provision in accordance with fluctuating customer expectations (Boyne 2004: 101). Repositioning is widely viewed as an innovative strategy, meaning that the quality of service provision is enhanced by new, innovative facilities and services (Boyne 2004: 100). Strategies are frequently combined: For example, the creation of entirely new services (repositioning) may also involve a structural reorganisation of the service provider.

The 3R-model is increasingly used as a concept to analyse the process of adaptation of public services in rural areas in response to demographic change (see e.g., Steinführer et al. 2014; Küpper 2011a). In order to cut-down operating costs, retrenchment has for instance been adopted in many cases in response to declining demand (Steinführer et al. 2014: 334). Whereas financially-motivated retrenchment strategies generally consist of (partial) closing-downs, reorganisation and repositioning strategies refer to a conversion towards a more flexible system in strong accordance to customer needs. However, it has to be mentioned that the 3R-strategy was originally developed to turnaround the performances of single organisations, whereas rural areas are confronted with comprehensive and manifold challenges concerning almost all public services and where piecemeal, sectoral adjustments will not ensure the success of future planning strategies. Moreover, if we do not consider peripheralisation as merely a decline in population (Beetz et al. 2008: 296), we also have to discuss adaptation strategies regarding selective out-migration, disconnection, dependence, and stigmatisation on top of a "simple" adaptation to shrinking demands.

Retrenchment can be defined as the " $R$ " that in almost all cases leads to (further) peripheralisation, both at the regional, the local and the individual level. Reducing, abandoning or centralising services of general interest is interlinked with all four characteristics of peripheralisation. The concept of a downward spiral in rural regions (Weber/Fischer 2010: 91, Fig. 2) triggered by a lack of jobs (disconnection) and selective migration (out-migration), ultimately leading to a loss of political clout and the emergence of a "no future" sentiment (stigmatisation) sheds light on the interlinkages and feedback loops of peripheralisation and infrastructural cutbacks. 
Fig. 2: Socio-demographic downward spiral

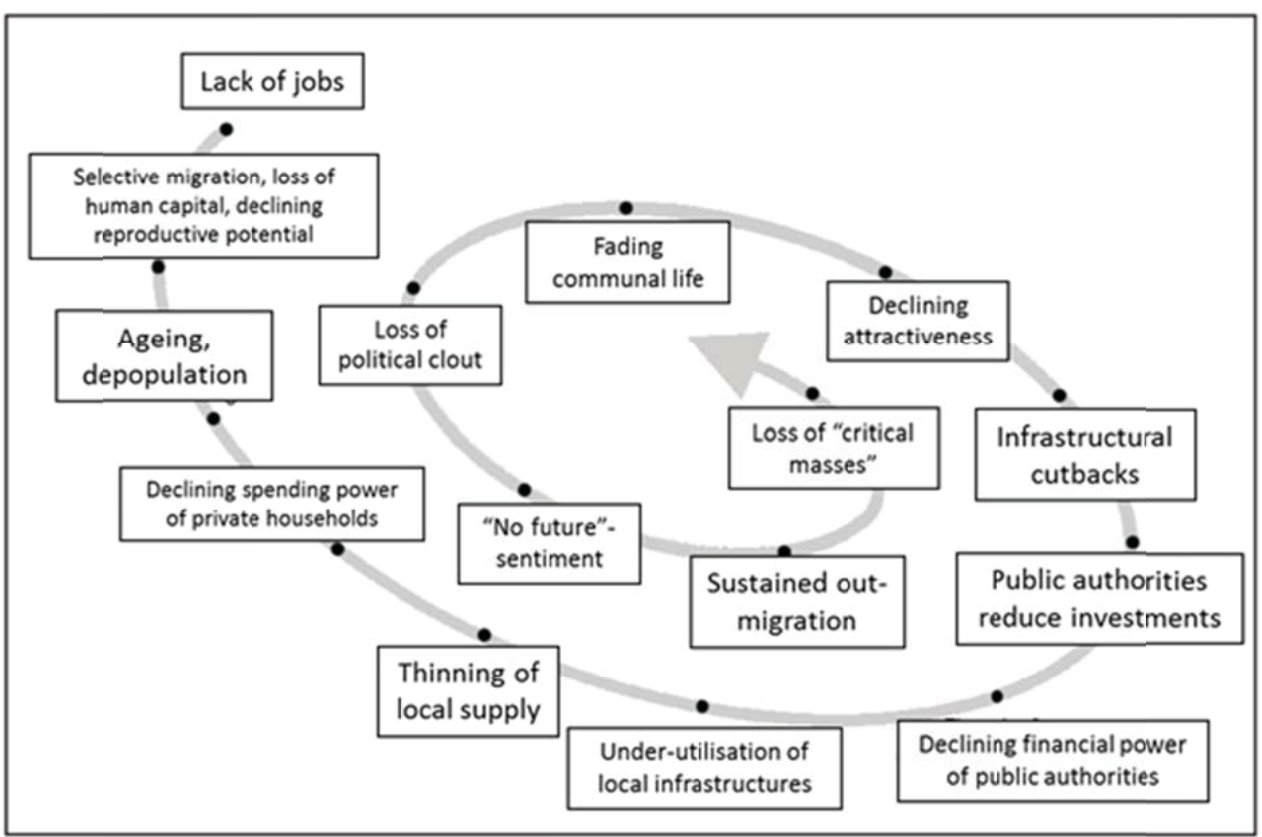

Source: Weber/Fischer (2010: 91)

The "dependence" aspect of peripheralisation is covered implicitly by the external decisions to reduce or close local infrastructures and the lacking assertiveness of the local population and local authorities to avert the implementation of aforementioned cuts. Repositioning and reorganisation might, however, be alternative strategies that policies of de-peripheralisation could be based on, i.e. potential ways out of the vicious circle of depopulation, ageing and disinvestment. This is, however, a difficult process and a matter of small steps. One problem is that - due to the multilevel nature of peripheralisation - comprehensive deperipheralisation policies based on repositioning and reorganisation strategies have to operate at various levels in order to be successful. It is, however, likely that already partial deperipheralisation policies might improve the development prospects of a given region and the quality of life of its inhabitants.

Deperipheralisation policies approaching disconnection would include measures to re-connect the peripheralised regions by improving infrastructures and fostering economic and social innovation (see section 2.2). By pursuing this strategy one, however, faces the challenge to find solutions that aim at more efficiency, less subsidies and better infrastructures as well as provision of services of general interest at the same time. Strengthening local self-government, increasing decision-making authorities as well as the financial room to manoeuvre of districts and municipalities is a frequently suggested (see e.g. Kröhnert et al. 2011: 73) and promising strategy to reduce the dependence of rural regions on decisions made at the federal or the 
Länder level. This would, however, result in more or less far-reaching reforms of the structure of German federalism. Tackling the problem of stigmatisation is even more complex. Stigmatisation has two spheres like regional identity: the sphere of stereotypes - the outsider's view - and the sphere of emotions - the insider's view. The former is linked to the image of a region, while the latter refers to the regional consciousness of the local population, a feeling of togetherness that is reproduced via social networks, schools and the local media (Raagmaa 2015: 290-291). Changing the outsider's view is an uphill struggle. The "dominant narratives, icons and images" used by the media tend to be "remarkably persistent" (Bürk 2013: 175) not least because the stigmatised places serve as metaphors for larger regions (e.g. East Germany) or socio-demographic processes (e.g. deindustrialisation, depopulation) (Bürk 2013).

In figure 3 we present possible strategies to improve the efficiency and to maintain the economic sustainability of different forms of public transport and cab companies in peripheralised rural regions. The list is non-exhaustive and based on conceptual considerations rather than concrete examples. We believe that three aspects should be highlighted. First of all, it is not always possible to link a specific strategy unambiguously to one of the three "Rs". Take for example the "replacement strategy" of line operation by demand-responsive transport schemes. If the timetable and the stops served remain the same and the only thing changing is that customers have to notify the operating company in advance that they wish to take the bus (the "L-Bus"-model; see Steinrück/Küpper 2010: 40-41), one can also classify the service changes as retrenchment. If the timetable, the number and location of stops have been expanded as a result of the replacement of line services by a demand-responsive transit scheme according to the needs to the customers (the "R-Bus"-model, Steinrück/Küpper 2010), the service adaptation would rather be a repositioning. One could finally refer to a reorganisation if the regular bus service would be replaced by a door-to-door-service without a real timetable (the "F-Bus"model, Steinrück/Küpper 2010).

Secondly, the impact of adaptation is necessarily selective. While people that depend on a certain service of general interest will be immensely affected if the service in question is reduced, discontinued or made less accessible, non-users may hardly notice the changes. The former have to develop their own adaptation strategies, they may have to invest more time, money and creativity to hold their lives together. In most cases, the reduction or discontinuation of services of general interest have to be counterbalanced by increasing (auto-)mobility, e.g. if schools, hospitals or shops are centralised. Since the young, the socially deprived and the elderly tend to be less (auto-)mobile, they are disproportionately affected by retrenchment. Proponents of retrenchment strategies (e.g. Holz-Rauet et al. 2010 who promote the "user-pays-principle") rarely pay attention to the social bias and the resulting danger of social exclusion for peripheralised social groups (see e.g. Hauss et al. 2006).

Thirdly, the "improvement" strategy should not be ruled out from the beginning. A recent representative survey carried out in Bavaria has shown that the percentage of people who use regional rail services on a regular basis has increased from 
Fig. 3: $\quad$ 3R-model: Possible adaptation strategies

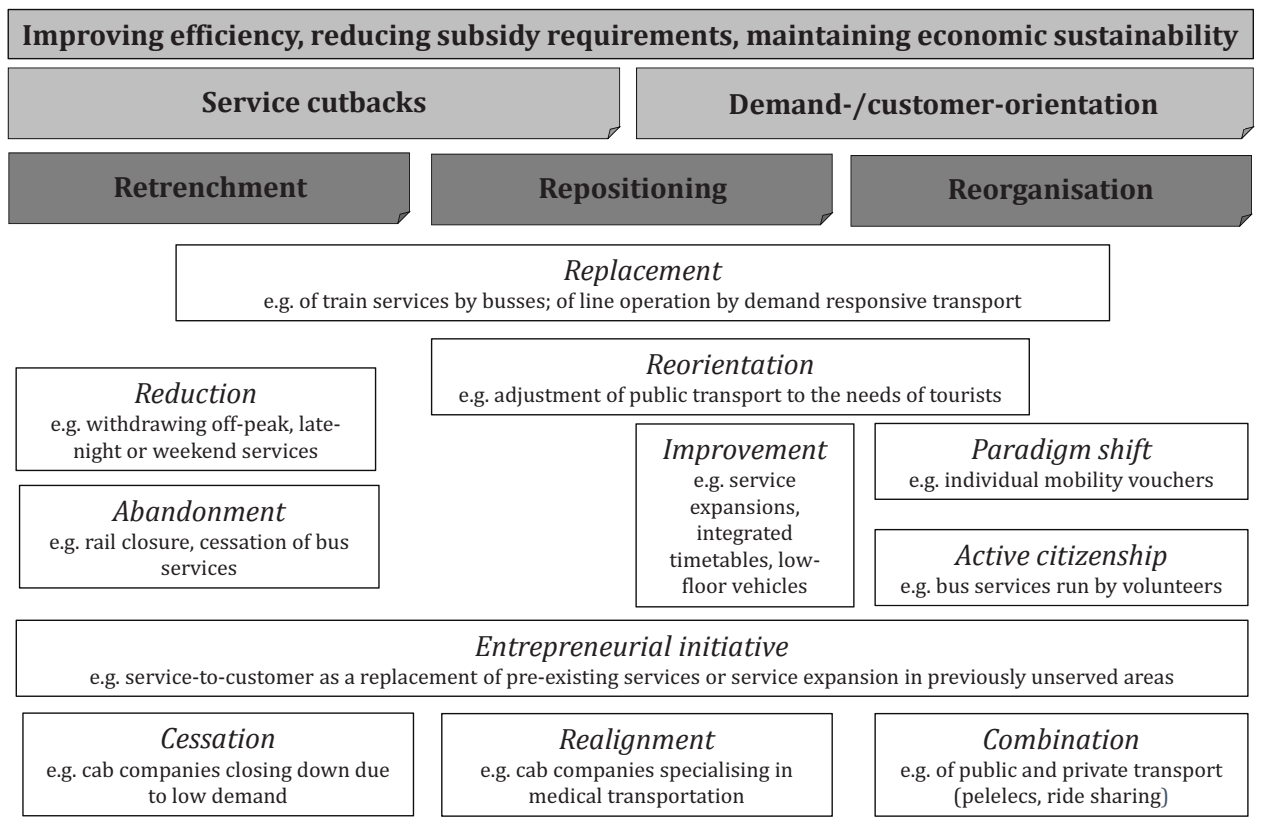

Source: own design

32 percent in 2005 to 50 percent of the total population in 2015 . The number of regular train users has increased by 86 percent in municipalities with less than 5.000 inhabitants - even though many of these rural communities are not served by passenger trains. The reasons why Bavarians take the train have also changed: Commuting to work or school is no longer the dominant motive - people increasingly use public transport for leisure trips or to go shopping. However, the improvement strategy does not seem to work for all means of transport: Bus ridership continues to decline (Naumann 2016). In order to legitimise the maintenance of public services in rural regions, an extension of the consumer base may be a promising strategy, especially if the service in question is of supra-regional importance. The "demographisation" of the debate on the future of rural infrastructures tends to ignore the fact that certain infrastructures and services (e.g. railway lines) are not only used by the shrinking local population, but also by non-locals. In other words: Local solutions (e.g. mobility vouchers, ride sharing) should only be pursued if the problem is basically local.

Finally, it has to be noted that demand-responsive transport schemes, which are frequently portrayed as the best solution for rural public transport (e.g. Heinze 2007) do not necessarily result in lower costs for the taxpayer and better and more frequent services for the users. Solutions like call-a-bus possibly improve the customer satisfaction and may lead to a higher demand, and thus meet the goal of providing a more customer- and demand-oriented rural public transport. However, 
the revenue-to-cost-ratio of demand-responsive transport schemes is very low in sparsely populated rural regions - as is the number of customers per trip (Küpper 2011b: 161). In other words: Due to frequent empty trips, demand-responsive transport schemes in sparsely populated rural regions can cause higher pollution than motorised personal transport and hence have a negative overall environmental balance (Steinrück/Küpper 2010: 2). Replacing non-economical services of general interest provided by the public sector by alternative solutions based on active citizenship and volunteerism is another "popular" theme in discussions and scientific policy advice that should be considered more critically, as will be shown in the next section.

\subsection{Active citizenship - the silver bullet for rural regions?}

In practice, advocating individual and innovative solutions, public participation and responsibility as a recipe for the successful adaptation of public services as well as of social and technical infrastructures collide with the harsh reality of declining and disconnected local human and social capital (Beetz et al. 2008: 300). Spatially selective processes of population decline have eroded the potential of human capital over the past two decades (Plöger/Weck 2014). There is a shortage of active and dedicated actors in many municipalities, not only concerning civil society, but also regarding local administrations and enterprises (Bernt/Liebmann 2013: 230). The likelihood to mobilise societal stakeholders and networks and to make use of their potential determines the amount of social capital within a community. A decline in human capital hence corresponds to weaker cooperation, loss of mutual trust among local actors and lesser knowledge exchange (Wiesinger 2007: 54). The loss of both human and social capital have a quantitative as well as a qualitative dimension: Whereas the quantitative dimension is merely related to a shrinking population, the qualitative dimension has to be framed as a complex outcome of peripheralisation and its dimensions: selective out-migration, dependence, disconnection, and stigmatisation. As a consequence, rural peripheries might increasingly lack important preconditions and capacities to cope with the challenges of demographic change (Nel/e 2015: 3). However, up to today, only little is known on the impact of shrinking quantitative and qualitative human resources on endogenous development practices in peripheral regions.

Other investigations discuss the possible function of human and social capital for civic engagement in terms of voluntarism in the provision of public services. They conclude that a sustainable and long-term provision of services of general interest based on voluntarism is questionable (Steinführer 2015: 15). The main reasons are: (1) active citizenship requires resources, notably human and social capital, which are not ubiquitous; (2) the number of possible volunteers will decrease in the future, especially in areas where they are most needed; and (3) even voluntary services and mutual help require a certain critical mass (Osti 2010: 303). This is especially true for Saxony-Anhalt where we can find the lowest level of voluntarism in Germany and one of the lowest ratios of contact points supporting civic engagement per capita (Generali/ISAB 2015: 14). Moreover, the already low number of potential 
volunteers is expected to decrease by more than 20 percent until 2025 relative to the 2006 level. According to this projection, the highest losses are likely to occur in rural districts which are already characterised by an accumulation of demographic and socio-economic problems such as unemployment, out-migration, low tax revenues, and structural economic problems (Swiaczny 2010: 207-208). Against this backdrop, Swiaczny (2010: 209) concludes that "those regions most in need of additional volunteer services to compensate for declining public provisions seem to be those, which are probably least able to generate enough additional volunteers because of their limited demographic capacity".

Both human and social capital are important prerequisites for place-based development strategies. The basic problem is, however, that active citizenship is not a ubiquitous resource, the same applies to social capital which is necessary for selfhelp. Depopulated and economically weak rural regions are often characterised by a lack of endogenous resources - both with respect to financial and social capital - necessary to tackle the problems of economic and infrastructural restructuring and to compensate the retreat of the state (Beetz et al. 2008: 300; Raagmaa 2015: 289). Processes of peripheralisation threaten the local stock of human and social capital, thus influencing the active involvement and ability to participate in regional development initiatives. Research assumes that a lack of human resources and social capital becomes obvious in volunteer services as compensations for declining public provisions. We additionally suggest to consider human resources (and their changes) for adaptation strategies under conditions of peripheralisation in general. A conceptualisation and implementation of comprehensive (adaptation) strategies with respect to sustainable regional development need a certain amount of intrinsic human resources.

\section{$4 \quad$ Conclusion and final thoughts}

Peripheralisation - i.e. the interconnectedness and interaction between out-migration, dependence, disconnection and stigmatisation - is a decisive, yet underestimated factor to any (rural) region's ability to maintain (or even enhance) an appropriate level of services of general interest and of technical and social infrastructures. The forces of peripheralisation (inter)act in a spatially selective way, which means that the problem's scope, methods of resolution and resources available are also region-specific. Shifting perspectives from one-size-fits-all solutions to locally-developed and context-specific adaptation strategies do ultimately imply that the most useful instruments for addressing the challenges of demographic change - self-help and active citizenship - not only depend on the local stakeholder's will to tackle the ensuing problems, but also on the complex network of power relations and dependencies they are embedded in. Keeping that in mind, the peripheralisation approach is helpful as it is a means to better understand why differences matter and also because it offers insights on how rural development policies that avoid eroding potentials for endogenous regional development should be designed. The peripheralisation concept has, however, some weaknesses. They become apparent when 
one tries to link the consequences of demographic change and the development of adaptation strategies. Peripheralisation is, after all, a concept employed in order to better understand regional disparities, but not a theory on which interventions could be based upon. This endeavour would require a better understanding of how rural societies work, of local institutional frameworks, of social structures and of stakeholder networks. The notions of dependence and disconnection are especially helpful in this context; both can also be used to analyse social relations at the micro level. One additional aspect - the "human factor" - is however needed to complete the picture. It is this "human factor" that matters with respect to the formation of such networks, which keeps them operating (or eventually breaks them up).

Declining and peripheralised regions can become "laboratories of demographic change" in which alternative and innovative adaptation strategies are tested. New actors, e.g. "spatial pioneers" and social entrepreneurs can make an appearance because the problems are so pressing and the approaches at hand (by trend retrenchment strategies) appear to be part of the problem rather than the solution. Against this backdrop, local stakeholders may be willing to try something new and different, the superordinate authorities may be willing to issue special permits for ideas that might be unsuitable in other contexts. In such a lab-like situation, ideas can be put into practice which would otherwise fail due to bureaucratic regulations or the opposition of local stakeholders. Active citizenship and volunteerism are important preconditions for this kind of de-peripheralisation. Local populations are, however, only to a certain degree willing and able to take over responsibilities that are perceived as core tasks of the public authorities. This willingness as well as the human and social capital necessary to design, implement and perpetuate voluntary services are not ubiquitous resources. And neither are external stakeholders automatically willing to support civil society initiatives - and this support is often crucial in order to put innovative ideas into practice. A voluntary transport scheme may, for instance, encounter opposition from local cab companies, face legal problems related to the Public Transport Act or be abandoned by the local council if too large subsidies are required. The "human factor" may also be the reason why active citizenship does not work. There are often few key actors, which are involved in multiple citizens' initiatives and serve as nodes for a given local society. But, what if two of these key actors become antagonists? Or if one of these pillars of society is no longer willing or able to keep up his/her voluntary work? The role of the "human factor" remains under-researched. It may be helpful in this respect to analyse failed attempts in order to better understand at what stage and for what reasons projects may collapse.

The peripheralisation concept could inspire holistic policies of de-peripheralisation. Peripheralisation posits that peripheries are not determined by geographic location, but by social and economic processes. It is hence safe to assume that the peripheralisation of a given region is reversible, i.e., the region in question is not forever doomed to be a periphery. In other words: In contrast to the self-reinforcing and largely inevitable vicious circles and downward spirals that constitute the heart of the demographisation discourse, the peripheralisation approach implies that if peripheries are produced and reproduced via out-migration, dependence, discon- 
nection, and stigmatisation, de-peripheralisation still remains possible. This could be achieved by policies aimed at fostering or enabling in-migration, independence (or autonomy), integration, and improvement of the region's external image. This is, however, a challenging enterprise. Given the relative lack of power of the peripheries, it remains questionable if a political framework based on the idea of de-peripheralisation can be initiated in the peripheries themselves or if it has to be the result of decisions increasing territorial or social cohesion made in the centres. Such a framework should be built on repositioning and reorganisation strategies as well as an empowerment of local actors and stakeholders and include measures that give the municipalities more financial and legal leeway to develop and implement tailor-made solutions - provided that such solutions do not jeopardise services and infrastructures of supra-regional importance and that they do not lead to a uncoordinated coexistence of isolated local solutions that would ultimately threaten the territorial cohesion of rural regions.

There is an abundance of promising suggestions to mitigate or even overcome the problems of dependence and disconnection, i.e., powerlessness and underfunding at the local level. However, to influence out-migration and stigmatisation is difficult, if at all possible. We may have to accept that there are regions, which permanently depend on external support. The question whether the inhabitants of such regions should have access to a well-developed infrastructure, networks, and adequate levels of services of general interest ultimately is a political, not a demographic question. Weakly frequented rural bus services or other infrastructures may be expensive for the taxpayer, but not expensive enough to destabilise the federal, state or municipal budgets. The basic question is if the society as a whole is willing to permanently subsidise some parts of the country or, to put it differently, if the benefits of maintaining an attractive and viable countryside outweigh its costs. This long overdue societal debate is suppressed by the demographisation of the debate on the future of rural areas.

\section{Acknowledgements}

The authors would like to express their gratitude to Birgit Glorius, Birgit Leick and the two anonymous reviewers for their helpful comments and remarks.

\section{References}

Balogh, Péter 2015: The Land of Storms and the region where the country's heart beats: changing images of peripherality in Hungary. In: Hungarian Geographical Bulletin 64,3: 219-231.

Barlösius, Eva; Neu, Claudia 2007: “Gleichwertigkeit - Ade?" Die Demographisierung und Peripherisierung entlegener ländlicher Räume. PROKLA. In: Zeitschrift für kritische Sozialwissenschaft 37,1: 77-92. 
Barlösius, Eva et al. 2011: Infrastrukturen neu denken: gesellschaftliche Funktionen und Weiterentwicklung. In: Hüttl, Reinhard et al. (Eds.): Globaler Wandel und Regionale Entwicklung. Anpassungsstrategien in der Region Berlin-Brandenburg. Heidelberg u.a.: Springer: 147-173.

BBSR (Bundesinstitut für Bau-, Stadt- und Raumforschung) 2015: Leitbilder und Konzepte der Raumordnung [http://www.bbsr.bund.de/BBSR/DE/Raumentwicklung/ RaumentwicklungDeutschland/Leitbilder/leitbilderkonzepte_node.html, 23.12.2015].

BBSR (Bundesinstitut für Bau-, Stadt- und Raumforschung) 2011: Raumordnungsbericht 2011. Bonn: BBR.

Beetz, Stephan 2008: Peripherisierung als räumliche Organisation sozialer Ungleichheit. In: Barlösius, Eva; Neu, Claudia (Eds.): Peripherisierung - eine neue Form sozialer Ungleichheit? Berlin: Berlin-Brandenburgische Akademie der Wissenschaften: 7-16.

Beetz, Stephan 2009: Analysen zum Entscheidungsprozess Jugendlicher zwischen "Gehen und Bleiben“. Die Relevanz kollektiver Orientierungen bei Migrationsentscheidungen ostdeutscher Jugendlicher. In: Schubarth, Wilfried; Speck, Karsten (Eds.): Regionale Abwanderung Jugendlicher. Theoretische Analysen, empirische Befunde und politische Gegenstrategien. Weinheim/München: Juventa: 135-151.

Beetz, Stephan 2013: "Landflucht"-Diskurs und territorialer Wettbewerb. In: Zeitschrift für Agrargeschichte und Agrarsoziologie 61,1: 48-61.

Beetz, Stephan; Huning, Sandra; Plieninger, Tobias 2008: Landscapes of Peripherization in North-Eastern Germany's Countryside: New Challenges for Planning Theory and Practice. In: International Planning Studies 13,4: 295-310 [doi: 10.1080/13563470802518909].

Berger, Peter; Kahlert, Heike 2006: Der demographische Wandel. Chancen für die Neuordnung der Geschlechterverhältnisse. Frankfurt am Main: Campus

Berlin-Institut für Bevölkerung und Entwicklung 2007: Gutachten zum demographischen Wandel im Land Brandenburg. Expertise im Auftrag des Brandenburgischen Landtags. Berlin.

Bernt, Matthias; Liebmann, Heike 2013: Zwischenbilanz: Ergebnisse und Schlussfolgerungen des Forschungsprojekts. In: Bernt, Matthias; Liebmann, Heike (Eds.): Peripherisierung, Stigmatisierung, Abhängigkeit? Deutsche Mittelstädte und ihr Umgang mit Peripherisierungsprozessen. Wiesbaden: Springer VS: 218-231 [doi: 10.1007/978-3531-19130-0].

BMVBS (Bundesministerium für Verkehr, Bau und Stadtentwicklung) 2006: Public services and demographic change. Proving of adaptation and development strategies in Demonstration Projects of Spatial Development [http://www.bbsr.bund.de/BBSR/ EN/Publications/BMVBS/SpecialPublication/1994_2006/DL_Publicservices.pdf? blob=publicationFile\& $\mathrm{v}=3,12.11 .2015]$.

Boyne, George 2004: A '3Rs' Strategy for Public Service Turnaround: Retrenchment, Repositioning, and Reorganization. In: Public Money and Management 24,2: 97-103 [urn:nbn:de:0156-37558].

Bürk, Thomas 2013: Voices From the Margin: The Stigmatization Process as an Effect of Socio-Spatial Peripheralization in Small-Town Germany. In: Fischer-Tahir, Andrea; Naumann, Matthias (Eds.): Peripheralization. The Making of Spatial Dependencies and Social Injustice. Wiesbaden: Springer VS: 168-186.

Canzler, Weert; Karl, Astrid 2010: Mit der Subjektförderung zur Mobilitätssicherung? Chancen und Barrieren für einen innovativen Landverkehr. In: Informationen zur Raumentwicklung 7: 505-515. 
Canzler, Weert; Knie, Andreas 2009: Auf dem Weg zum Gewährleistungsstaat: Netzvermarktung und Infrastrukturpolitik für die schrumpfende Gesellschaft. In: Neu, Claudia (Ed.): Daseinsvorsorge. Eine gesellschaftswissenschaftliche Annäherung. Wiesbaden: Springer VS: 97-111 [doi: 10.1007/978-3-531-91876-1].

Copus, Andrew 2001: From Core-periphery to Polycentric Development: Concepts of Spatial and Aspatial Peripherality. In: European Planning Studies 9, 4: 539-551 [doi: 10.1080/713666491]

Ebenrett, Heinz; Hansen, Dieter; Puzicha, Klaus 2003: Verlust von Humankapital in Regionen mit hoher Arbeitslosigkeit. In: Aus Politik und Zeitgeschichte B6-7/2003: 25-31.

Einig, Klaus 2015: Gewährleisten Zentrale-Orte-Konzepte gleichwertige Lebensverhältnisse bei der Daseinsvorsorge? In: Informationen zur Raumentwicklung 1: 45-55.

Einig, Klaus; Jonas, Andrea 2009: Ungleichwertige Lebensverhältnisse in Deutschland. In: Europa Regional 17,3: 130-146.

Elbe, Sebastian; Müller, Rainer 2015: Gleichwertigkeit als Bürgeraufgabe. Partizipation der Zivilgesellschaft = Überforderung der Zivilgesellschaft? In: Informationen zur Raumentwicklung 1: 57-70.

Ermann, Ulrich; Lang, Thilo; Megerle, Marce/ 2012: Weltmarktführer abseits der Agglomerationsräume. Nationalatlas aktuell 6 (10.2012) 11 [18.10.2012].

Eskelinen, Heikki; Snickars, Folke 1995: Competitive European Peripheries? An Introduction. In: Eskelinen, Heikki; Snickars, Folke (Eds.): Competitive European Peripheries. Springer: Heidelberg/Berlin: 1-14 [doi: 10.1007/978-3-642-79955-6_1].

European Commission 2006: Die EU-Politik zur Förderung der Entwicklung des ländlichen Raumes 2007-2013. Fact Sheet [http://ec.europa.eu/agriculture/publi/fact/ rurdev2007/de_2007.pdf, 26.4.2013].

Faber, Kerstin 2013: Raumpioniere. Vom Bürgerbus bis zur Schulgründung - neue Wege der Daseinsvorsorge in ländlichen Regionen. In: AgrarBündnis (Ed.): Der kritische Agrarbericht. Hamm: ABL Verlag: 161-164.

Federwisch, Tobias 2014: Soziales Unternehmertum im ländlichen Raum: Perspektiven einer neuen Anpassungsstrategie. In: Grotheer, Swantje; Schwöbel, Arne; Stepper, Martina (Eds.): Nimm's sportlich - Planung als Hindernislauf. Hannover: ARL: 98-109.

Fischer-Tahir, Andrea; Naumann, Matthias 2013: Introduction: Peripheralization as the Social Production of Spatial Dependencies and Injustice. In: Fischer-Tahir, Andrea; Naumann, Matthias (Eds.): Peripheralization. The Making of Spatial Dependencies and Social Injustice. Wiesbaden: Springer VS: 9-26 [doi: 10.1007/978-3-531-19018-1].

Generali; ISAB (Eds.) 2015: Generali Engagementatlas 2015. Rolle und Perspektiven Engagement unterstützender Einrichtungen in Deutschland. Köln/Bernkastel-Kues: Generali; ISAB.

Halfacree, Keith 2012: Heterolocal Identities? Counter-Urbanisation, Second Homes, and Rural Consumption in the Era of Mobilities. In: Population, Space and Place 18,2: 209-224 [doi: 10.1002/psp.665].

Hauss, Friedrich; Land, Rainer; Willisch, Andreas 2006: Umbruch der Agrarverfassung und Zerfall der ländlichen Gesellschaft. In: Aus Politik und Zeitgeschichte Heft 37/2006: 31-38.

Heinze, G. Wolfgang 2007: Öffentlicher Verkehr und demographischer Wandel: Chancen für Nordostdeutschland. In: Beetz, Stephan (Ed.): Die Zukunft der Infrastrukturen in ländlichen Räumen. Berlin: Berlin-Brandenburgische Akademie der Wissenschaften: 21-30. 
Holz-Rau, Christian; Günthner, Stephan; Krummheuer, Florian 2010: Daseinsvorsorge ist keine Dortseinsvorsorge. Hinweise zur Planung in dünn besiedelten Räumen. In: Informationen zur Raumentwicklung 7: 489-504.

Hyll, Walter; Schneider, Lutz 2011: Grundschulschließungen als Katalysator von Wanderungsbewegungen? In: Wirtschaft im Wandel 17,6: 217-225.

Kawka, Rupert 2015: Gleichwertigkeit messen. In: Informationen zur Raumentwicklung 1: 71-81.

Keim, Karl-Dieter 2006: Peripherisierung ländlicher Räume. In: Aus Politik und Zeitgeschichte 37/2006: 3-7.

Kersten, Jens; Neu, Claudia; Vogel, Berthold 2015: Regionale Daseinsvorsorge. Begriffe, Indikatoren, Gemeinschaftsaufgabe. In: Friedrich-Ebert-Stiftung (Ed.): WISO Diskurs. Expertisen und Dokumentationen zur Wirtschafts- und Sozialpolitik [http://www. sofi-goettingen.de/fileadmin/Berthold_Vogel/Material/regionale.daseinsvorsorge. pdf, 25.11.2015].

Kersten, Jens 2006: Daseinsvorsorge und demographischer Wandel: Wie ändert sich das Raum- und Staatsverständnis? In: Raumforschung und Raumordnung 4: 245-257.

Klingholz, Reiner 2015: Vielfalt statt Gleichwertigkeit - Die Regionalpolitik braucht eine neue Zielsetzung. In: Informationen zur Raumentwicklung 1: 23-27.

Kröhnert, Steffen et al. 2011: Die Zukunft der Dörfer. Zwischen Stabilität und demographischem Niedergang. Berlin: Berlin-Institut für Bevölkerung und Entwicklung.

Kühn, Manfred 2015: Peripheralization: Theoretical Concepts Explaining Socio-Spatial Inequalities. In: European Planning Studies 23,2: 367-378 [doi: 10.1080/09654313.2013.862518].

Kühn, Manfred; Bernt, Matthias 2013: Peripheralization and Power-Theoretical Debates. In: Fischer-Tahir, Andrea; Naumann, Matthias (Eds.): Peripheralization. The Making of Spatial Dependencies and Social Injustice. Wiesbaden: Springer VS: 302-317.

Kühn, Manfred; Weck, Sabine 2013: Peripherisierung - ein Erklärungsansatz zur Entstehung von Peripherien. In: Bernt, Matthias; Liebmann, Heike (Eds.): Peripherisierung, Stigmatisierung, Abhängigkeit? Deutsche Mittelstädte und ihr Umgang mit Peripherisierungsprozessen. Wiesbaden: Springer VS: 24-46 [doi: 10.1007/978-3-531-191300_2].

Kühntopf, Stephan; Stedtfeld, Susanne 2012: Wenige junge Frauen im ländlichen Raum: Ursachen und Folgen der selektiven Abwanderung in Ostdeutschland. BIB Working Paper 3/2012. Wiesbaden: Bundesinstitut für Bevölkerungsforschung.

Küpper, Patrick 2011a: Sicherung der Daseinsvorsorge durch regionale Kooperation Erfahrungen aus ländlichen Räumen. In: Growe, Anna et al. (Eds.): Polyzentrische Stadtregionen - Die Region als planerischer Handlungsraum. Arbeitsberichte der ARL 3. 14. Junges Forum der ARL. Hannover: 86-98.

Küpper, Patrick 2011b: Auf dem Weg zu einem Grundangebot von Mobilität in ländlichen Räumen - Probleme, Ursachen und Handlungsoptionen. In: Hege, Hans-Peter et al. (Eds.): Schneller, öfter, weiter? Perspektiven der Raumentwicklung in der Mobilitätsgesellschaft. ARL: Hannover: 152-168.

Lang, Thilo 2012: Shrinkage, Metropolization and Peripheralization in East Germany. In: European Planning Studies 20,10: 1747-1754 [doi: 10.1080/09654313.2012.713336].

Lang, Thilo 2015: Socio-economic and political responses to regional polarisation and socio-spatial peripheralisation in Central and Eastern Europe: a research agenda. In: Hungarian Geographical Bulletin 64,3: 171-185. 
Laschewski, Lutz 2009: The Formation and Destruction of Social Capital - Lessons from East German Rural Restructuring. Eastern European Countryside 15: 91-110 [doi: 10.2478/v1030-009-0006-4].

Leibert, Tim 2013: The Peripheralization of Rural Areas in Post-socialist Central Europe: A Case of Fragmenting Development? Lessons from Rural Hungary. In: Fischer-Tahir, Andrea; Naumann, Matthias (Eds.): Peripheralization. The Making of Spatial Dependencies and Social Injustice. Wiesbaden: Springer VS: 101-120.

Leibert, Tim 2015: Abwanderung Jugendlicher aus postsozialistischen ländlichen Räumen. In: Geographische Rundschau 67,9: 34-41.

Leibert, Tim 2016: She leaves, he stays? Sex-selective migration in rural East Germany. In: Journal of Rural Studies 43: 267-279 [doi:10.1016/j.jrurstud.2015.06.004].

Leibert, Tim; Köppl, Simon 2015: Fortschreibung des Handlungskonzepts für eine nachhaltige Bevölkerungspolitik Sachsen-Anhalts. Baustein 1: Wissenschaftlich-analytischer Teil. Leipzig: IfL. Unpublished report.

Leibert, Tim; Wiest, Karin 2012: SEMIGRA Final Report - Annex 2A. Case Study Report: Sachsen-Anhalt. Leipzig/Luxembourg: IfL; ESPON.

Looker, Dianne; Naylor, Ted 2009: 'At risk' of being rural? The experience of rural youth in a risk society. In: Journal of rural and community development 4,2: 39-64.

Milbourne, Paul; Kitchen, Lawrence 2014: Rural mobilities: Connecting movement and fixity in rural places. In: Journal of Rural Studies 34: 326-336 [doi:10.1016/j.jrurstud.2014.01.004].

Naumann, Matthias; Reichert-Schick, Anja 2015: Ländliche Infrastrukturen - Risiken, Anpassungserfordernisse und Handlungsoptionen. In: Raumforschung und Raumordnung 73,1: 1-3 [doi: 10.1007/s13147-015-0329-8].

Naumann, Thomas 2016: Freizeit, Erholung und Einkaufen führende Fahrtzwecke im ÖV. In: Stadtverkehr 61,10: 26-27.

Nelle, Anja B. 2015: Tackling human capital loss in shrinking cities: urban development and secondary school improvement in Eastern Germany. In: European Planning Studies 11: 1-19 [doi: 10.1080/09654313.2015.1109611].

Neu, Claudia 2006: Territoriale Ungleichheit - eine Erkundung. In: Aus Politik und Zeitgeschichte 37/2006: 8-15.

$\mathrm{Neu}$, Claudia 2009: Daseinsvorsorge und territoriale Ungleichheit. In: Neu, Claudia (Ed.): Daseinsvorsorge. Eine gesellschaftswissenschaftliche Annäherung. Wiesbaden: Springer VS: 80-96.

Osti, Giorgio 2010: Mobility Demands and Participation in Remote Rural Areas. In: Sociologia Ruralis 50,3: 296-310 [doi: 10.1111/j.1467-9523.2010.00517.x].

Paasi, Anssi 1995: The Social Construction of Peripherality: the Case of Finland and the Finnish-Russian Border Area. In: Eskelinen, Heikki; Snickars, Folke (Eds.): Competitive European Peripheries. Springer: Heidelberg/Berlin: 235-258 [doi: 10.1007/978-3-64279955-6_12].

Plöger, Jörg; Weck, Sabine 2014: Confronting Out-Migration and the Skills Gap in Declining German Cities. In: European Planning Studies 22,2: 437-455.

Raagmaa, Garri 2015: Territorial Governance and Core-Periphery Relations: The Implications of European Policy Concepts for Central and Eastern Europe. In: Lang, Thilo et al. (Eds.): Understanding Geographies of Polarization and Peripheralization. Perspectives from Central and Eastern Europe and Beyond. Basingstoke: Palgrave Macmillan: 287-308. 
Reichert-Schick, Anja 2013: Wüstungen - zur potentiellen Renaissance eines historischen Phänomens. In: Zeitschrift für Agrargeschichte und Agrarsoziologie 61,1: 27-47.

Rolfes, Manfred; Mohring, Katharina 2009: Diskursanalysen zur Abwanderung ostdeutscher Jugendlicher. Einige Überlegungen zum Diskurs über die Abwanderung aus Brandenburg. In: Schubarth, Wilfried; Speck, Karsten (Eds.): Regionale Abwanderung Jugendlicher. Theoretische Analysen, empirische Befunde und politische Gegenstrategien. Weinheim, München: Juventa: 69-90.

Seibel, Frank 2014: Schulrebellen gewinnen vorm Verfassungsgericht. In: Sächsische Zeitung 11.12.2014 [http://www.sz-online.de/sachsen/schulrebellen-gewinnen-vormverfassungsgericht-2992998.html, 26.10.2016].

Speck, Karsten; Schubarth, Wilfried 2009: Regionale Abwanderung Jugendlicher als Teil des demographischen Wandels - eine ostdeutsche oder gesamtdeutsche Herausforderung? In: Schubarth, Wilfried; Speck, Karsten (Eds.): Regionale Abwanderung Jugendlicher. Theoretische Analysen, empirische Befunde und politische Gegenstrategien. Weinheim/München: Juventa: 11-40.

Spoor, Max 2013: Multidimensional Social Exclusion and the 'Rural-Urban Divide' in Eastern Europe and Central Asia. Sociologia Ruralis 53,2: 139-157 [DOI: 10.1111/ soru.12008].

Steinführer, Annett 2015: Bürger in der Verantwortung. Veränderte Akteursrollen in der Bereitstellung ländlicher Daseinsvorsorge. In: Raumforschung und Raumordnung 73,1: 5-16 [doi: 10.1007/s13147-014-0318-3].

Steinführer, Annett; Küpper, Patrick; Tautz, Alexandra 2014: Anpassen und Bewältigen: Strategien zur Sicherung von Lebensqualität in einer schrumpfenden Alterungsregion. In: Comparative Population Studies 39,2: 319-344 [urn:nbn:de:bib-cpos-2014-07de9].

Steinrück, Barbara; Küpper, Patrick 2010: Mobilität in ländlichen Räumen unter besonderer Berücksichtigung bedarfsgesteuerter Bedienformen des ÖPNV. Arbeitsberichte aus der vTI-Agrarökonomie 02/2010. Braunschweig: vTI Institut für Ländliche Räume.

Steffen, Tilman 2013: Rebellion im Klassenzimmer. In: Die Zeit, 18.01.2013 [http://www. zeit.de/gesellschaft/schule/2013-01/schulrebellen-sachsen-mittelschule-oberlausitz, 26.10.2016].

Steffens, Marie-Luise; Kröhnert, Steffen 2009: Strategien zum Umgang mit Abwanderung und demographischer Schrumpfung für die Landes- und Kommunalpolitik. In: Schubarth, Wilfried; Speck, Karsten (Eds.): Regionale Abwanderung Jugendlicher. Theoretische Analysen, empirische Befunde und politische Gegenstrategien. Weinheim/München: Juventa: 207-221.

Stockdale, Aileen 2006: Migration: Pre-requisite for rural economic regeneration. In: Journal of Rural Studies 22,3: 354-366 [doi:10.1016/j.jrurstud.2005.11.001].

Swiaczny, Frank 2010: Implications of demographic change for civil society in Germany. In: Journal of Population Research 27,3: 193-211 [doi: 10.1007/s12546-010-9041-2].

Walsh, Deatra 2012: Using Mobility to Gain Stability: Rural Household Strategies and Outcomes in Long-Distance Labour Mobility. In: Journal of Rural and Community Development 7,3: 123-143.

Walshe, Kieran et al. 2004: Organizational Failure and Turnaround: Lessons for Public Services from the For-Profit Sector. In: Public Money \& Management 24,4: 201-208 [doi: 10.1111/j.1467-9302.2004.00421.x].

Weber, Andreas; Klingholz, Reiner 2009: Demographischer Wandel. Ein Politikvorschlag unter besonderer Berücksichtigung der Neuen Länder. Berlin: Berlin-Institut für Bevölkerung und Entwicklung. 
Weber, Gerlind; Fischer, Tatjana 2010: Gehen oder Bleiben? Die Motive des Wanderungs- und Bleibeverhaltens junger Frauen im ländlichen Raum der Steiermark und die daraus resultierenden Handlungsoptionen im Rahmen der Lokalen Agenda 21 Prozesse. Wien: IRUB.

Wiesinger, Georg 2007: The importance of social capital in rural development, networking and decision-making in rural areas. In: Journal of Alpine Research 95,4: 43-56 [doi: 10.4000/rga.354].

Wiest, Karin; Leibert, Tim 2013: Wanderungsmuster junger Frauen im ländlichen Sachsen-Anhalt - Implikationen für zielgruppenorientierte Regionalentwicklungsstrategien. In: Raumforschung und Raumordnung 71,6: 455-469 [doi: 10.1007/s13147-0130257-4].

Wiest, Karin 2016: Migration and everyday discourses: Peripheralisation in rural Saxony-Anhalt from a gender perspective. In: Journal of Rural Studies 43: 280-290 [doi:10.1016/j.jrurstud.2015.03.003].

Dr. Tim Leibert $(\bowtie)$. Leibniz Institute for Regional Geography. Leipzig, Germany.

E-mail: T_Leibert@ifl-leipzig.de

URL:https://www.ifl-leipzig.de/en/about-ifl/staff/leibert-tim.html

Sophie Golinski. Ministry of Regional Development and Transport Saxony-Anhalt. Magdeburg, Germany. E-mail: Sophie.Golinski@mlv.sachsen-anhalt.de

URL: https://mlv.sachsen-anhalt.de/fachthemen/raumordnung-und-landesentwicklung/ interreg-projekte/rumobil/\# 


\section{Comparative Population Studies}

wWW.comparativepopulationstudies.de

ISSN: 1869-8980 (Print) - 1869-8999 (Internet)

\section{Published by}

Prof. Dr. Norbert F. Schneider

Federal Institute for Population Research D-65180 Wiesbaden / Germany

\section{(cc) BY-SA}

2017

\section{Managing Editor}

Frank Swiaczny

\section{Assistant Managing Editor}

Katrin Schiefer

\section{Copy Editor}

(Selected Articles in German)

Dr. Evelyn Grünheid

\section{Layout}

Beatriz Feiler-Fuchs

E-mail: cpos@bib.bund.de

\section{Scientific Advisory Board}

Paul Gans (Mannheim)

Karsten Hank (Cologne)

Johannes Huinink (Bremen)

Michaela Kreyenfeld (Rostock)

Marc Luy (Vienna)

Notburga Ott (Bochum)

Peter Preisendörfer (Mainz)

Nikola Sander (Groningen)

Zsolt Spéder (Budapest)

\section{Board of Reviewers}

Martin Abraham (Erlangen)

Laura Bernardi (Lausanne)

Hansjörg Bucher (Bonn)

Claudia Diehl (Konstanz)

Andreas Diekmann (Zurich)

Gabriele Doblhammer-Reiter (Rostock)

Jürgen Dorbritz (Wiesbaden)

Anette Eva Fasang (Berlin)

E.-Jürgen Flöthmann (Bielefeld)

Alexia Fürnkranz-Prskawetz (Vienna)

Beat Fux (Salzburg)

Joshua Goldstein (Berkeley)

Sonja Haug (Regensburg)

Hill Kulu (Liverpool)

Aart C. Liefbroer (The Hague)

Kurt Lüscher (Konstanz)

Emma Lundholm (Umeå)

Nadja Milewski (Rostock)

Dimiter Philipov (Vienna)

Roland Rau (Rostock)

Tomáš Sobotka (Vienna)

Jeroen Spijker (Barcelona)

Olivier Thévenon (Paris)

Helga de Valk (Brussels)

Heike Trappe (Rostock)

Michael Wagner (Cologne) 